О.Ю. Смольков ${ }^{1}$, В.І. Коцюруба ${ }^{1}$, К.Ю. Гунбін ${ }^{2}$

${ }^{1}$ Національний університет оборони України ім. I. Черняховського, Київ

${ }^{2}$ Національна академія Наџіональної гвардії України, Харків

\title{
НАУКОВО-МЕТОДИЧНИЙ ПІДХІД ЩОДО ОБҐРУНТУВАННЯ ВИМОГ ДО ДИСТАНЦІЙНО-КЕРОВАНИХ РАДІОЛОКАЦІЙНИХ КОМПЛЕКСІВ ВИЯВЛЕННЯ ВИБУХОВИХ ПРИСТРОЇВ 3 НЕКОНТАКТНИМИ ДАТЧИКАМИ ЦІЛІ
}

Збільшення застосування вибухових пристроїв з неконтактними датчиками цілі визначає необхідність поглибленого дослідження питань розвитку засобів пошуку та виявлення вибухових пристроїв даного типу. Запропоновано вдосконалену комплексну методику технічного обгрунтування тактико-технічних вимог до дистанційно-керованих радіолокаційних комплексів пошуку та виявлення вибухових пристроїв з неконтактними датчиками иілі.

Ключові слова: вибухові пристрої, неконтактний датчик ияілі, дистанційно-керований радіолокаційний комплекс.

\section{Вступ}

Постановка проблеми. Аналіз досвіду підготовки та ведення бойових дій на сході України, а також у воєнних конфліктах на території інших держав [1] показав значне збільшення інтенсифікації застосування мінної зброї зі зміщенням пріоритетів у бік саморобних вибухових пристроїв. Вказаний факт свідчить про значне збільшення обсягів ведення наземної мінної війни, що у свою чергу загострює загальносвітову проблему протимінної діяльності, одним із найважливіших заходів якої $є$ розмінування місцевості та об'єктів.

Розмінування як процес може мати ознаки бойового (оперативного) або гуманітарного характеру [2]. Значне перевищення темпів розвитку та інтенсивності застосування мінної зброї у порівнянні із засобами розмінування [3], обумовлюють актуальність проблемного питання щодо забезпечення потрібного рівня їх технічної досконалості. У зв'язку зі збільшенням частки застосування вибухових пристроїв (ВП) із неконтактними датчиками цілі (НДЦ) підвищилась потреба поглибленого дослідження питань розвитку засобів пошуку та виявлення ВП даного типу. При цьому особлива увага звертається на забезпечення потрібного рівня якості процесів розмінування, зменшення до мінімального рівня вибухонебезпечних загроз та зниження вартості робіт з розмінування.

Аналіз останніх досліджень і публікацій. Аналіз попередніх досліджень як зарубіжних, так і вітчизняних дослідників [4-7] показав, що питанням підповерхневої локації аномалій приділялося багато уваги. Причому найбільшу ефективність під час виявлення ВП показали радіолокаційні методи. Для виявлення ВП з НДЦ найбільш доцільним виявися метод нелінійної радіолокації (НРЛ). У попередніх дослідженнях не враховувались ймовірнісні показники та вимоги керівних документів 3 питань якості розмінування, відсутній комплексний підхід до обгрунтування тактико-технічних вимог до дистанційно-керованих радіолокаційних комплексів (ДКРЛК) виявлення ВП з НДЦ.

Мета статті. Метою статті є висвітлення науково-методичного підходу щодо обгрунтування тактико-технічних вимог до ДКРЛК виявлення ВП 3 НДЦ.

\section{Виклад основного матеріалу}

Для визначення тактико-технічних вимог до ДКРЛК пошуку та виявлення ВП з НДЦ запропоновано удосконалену комплексну методику технічного обгрунтування тактико-технічних вимог до ДКРЛК пошуку та виявлення ВП з НДЦ (рис. 1), сутність якої полягає у наступному. На основі вимог, закладених у стратегії національної безпеки та оборони України, інших законодавчих актах та керівних документах, у блоці 1 здійснюють аналіз оперативнотактичних вхідних даних для засобів інженерного озброєння та оперативно-тактичних вимог (блок 2) до системи засобів розмінування місцевості та об'єктів.

Під час розробки варіантів застосування засобів розмінування при бойовому або гуманітарному розмінуванні у блоці 3 виділяють базові властивості засобів пошуку та виявлення ВП з НДЦ, для яких на підгрунті стандартів та науково-технічних даних визначають часткові параметри (блок 4).

У блоці 5 обирають показники та характеристики ДКРЛК пошуку та виявлення ВП з НДЦ, до яких висуваються вимоги, та критерії оцінювання за частковими показниками (блок 6). Узагальнений 
критерій обгрунтовують у блоці 7 за основним показником із врахуванням вимог міжнародних стандартів $з$ протимінної діяльності.

Блок 8 - удосконалюють математичну модель пошуку та виявлення ВП з НДЦ методом НРЛ, а у блоці 9 розробляють регресійну модель розповсюдження радіохвиль в укриваючих середовищах. Шляхом моделювання (блок 10) розраховують значення параметрів за частковими та основним показниками.

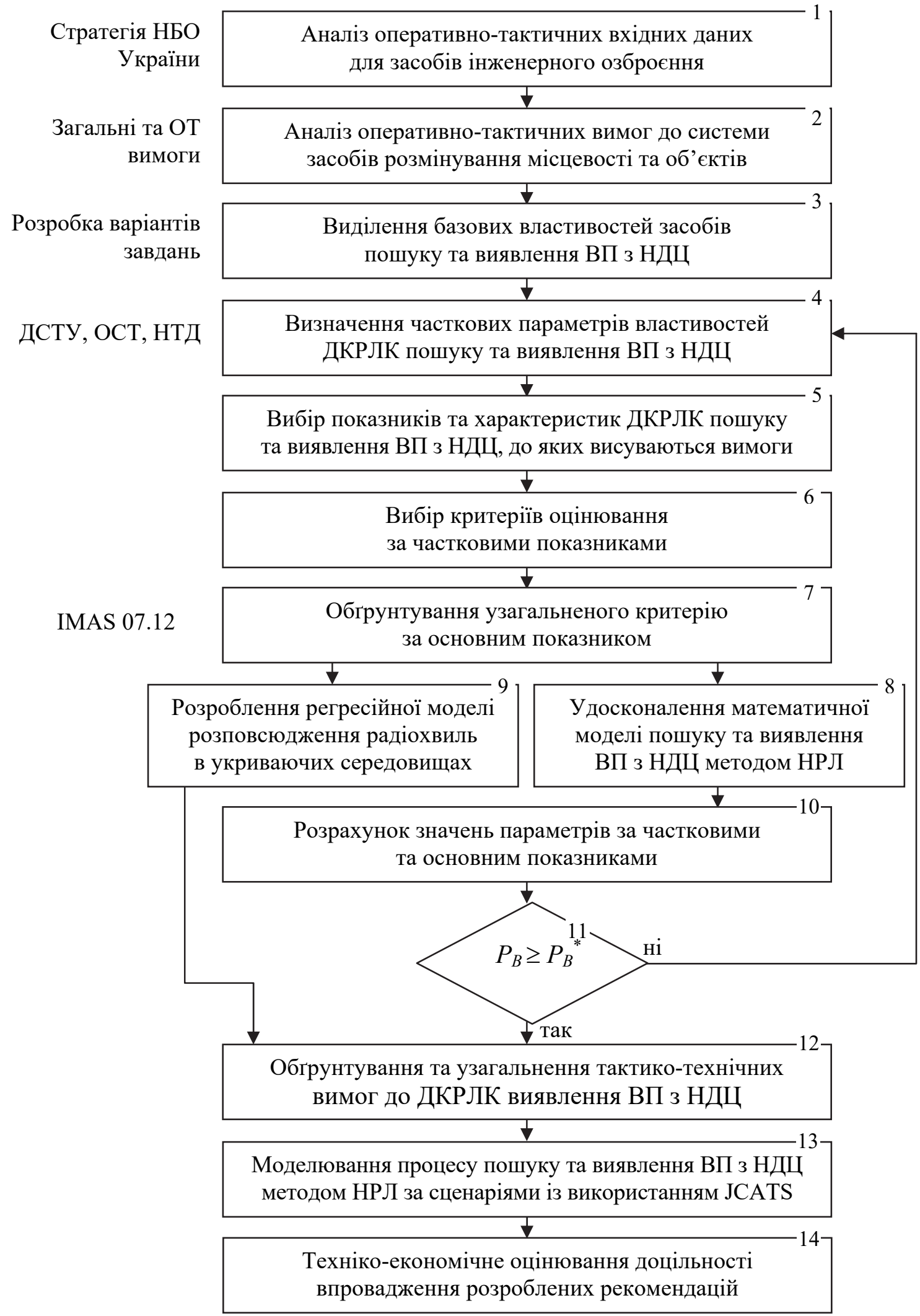

Рис. 1. Структурно-логічна схема удосконаленої комплексної методики технічного обгрунтування тактико-технічних вимог до ДКРЛК виявлення ВП з НДЦ Джерело: розроблено авторами. 
За обраним узагальненим критерієм у блоці 11 оцінюють ефективність процесу пошуку та виявлення ВП з НДЦ. При незадоволенні вимоги здійснюється коригування вхідних параметрів властивостей засобів (комплексів) пошуку та виявлення ВП з НДЦ (блок 12). У разі задоволення вимоги критерію обгрунтовують та узагальнюють тактико-технічні вимоги до перспективного ДКРЛК виявлення ВП з НДЦ.

Із використанням сертифікованого середовища JCATS у блоці 13 здійснюють моделювання процесу пошуку та виявлення ВП з НДЦ методом НРЛ за сценаріями виконання бойових та спеціальних завдань. Блок $14 \epsilon$ реалізацією техніко-економічного оцінювання доцільності впровадження розроблених рекомендацій.

Отже, запропонована комплексна методика технічного обгрунтування тактико-технічних вимог до ДКРЛК виявлення ВП з НДЦ включає сукупність процедур, розроблених і удосконалених математичних моделей та дозволяє комплексно обгрунтувати вимоги до основних характеристик та показників ефективності ДКРЛК пошуку і виявлення ВП з НДЦ.

Аналіз створення засобів (комплексів) пошуку та виявлення ВП попередніх років, відомої літератури $з$ цього питання, проведені дослідження дозво- ляють сформулювати основні властивості засобів (комплексів) пошуку та виявлення ВП з НДЦ, які є визначальними для їх концептуального образу.

Для дослідження вказаного проблемного питання (оцінювання ефективності функціонування ДКРЛК пошуку та виявлення ВП з НДЦ) на основі результатів попередніх досліджень розроблено та запропоновано структурний образ перспективного пошукового пристрою методом нелінійної радіолокації на повітряній платформі [8]. Отже, застосування пристрою пошуку та виявлення ВП з НДЦ на основі методу нелінійної радіолокації (НРЛ) передбачається шляхом монтажу його на дистанційнокерованій платформі (ДКП), зокрема, БпЛА коптерного типу.

Недоліками існуючого пристрою НРЛ, наприклад [9-10], є те, що він не дозволяє здійснювати фіксацію, передачу координат та маркування місця встановлення ВП з НДЦ, що володіють нелінійними характеристиками. Також зазначені пристрої не дозволяють здійснювати формування та відображення геоінформаційного шару мінної обстановки у реальному масштабі часу.

Суть технічного рішення наведена на рис. 2, де подано удосконалену структурно-логічну модель перспективного пристрою НРЛ на ДКП.
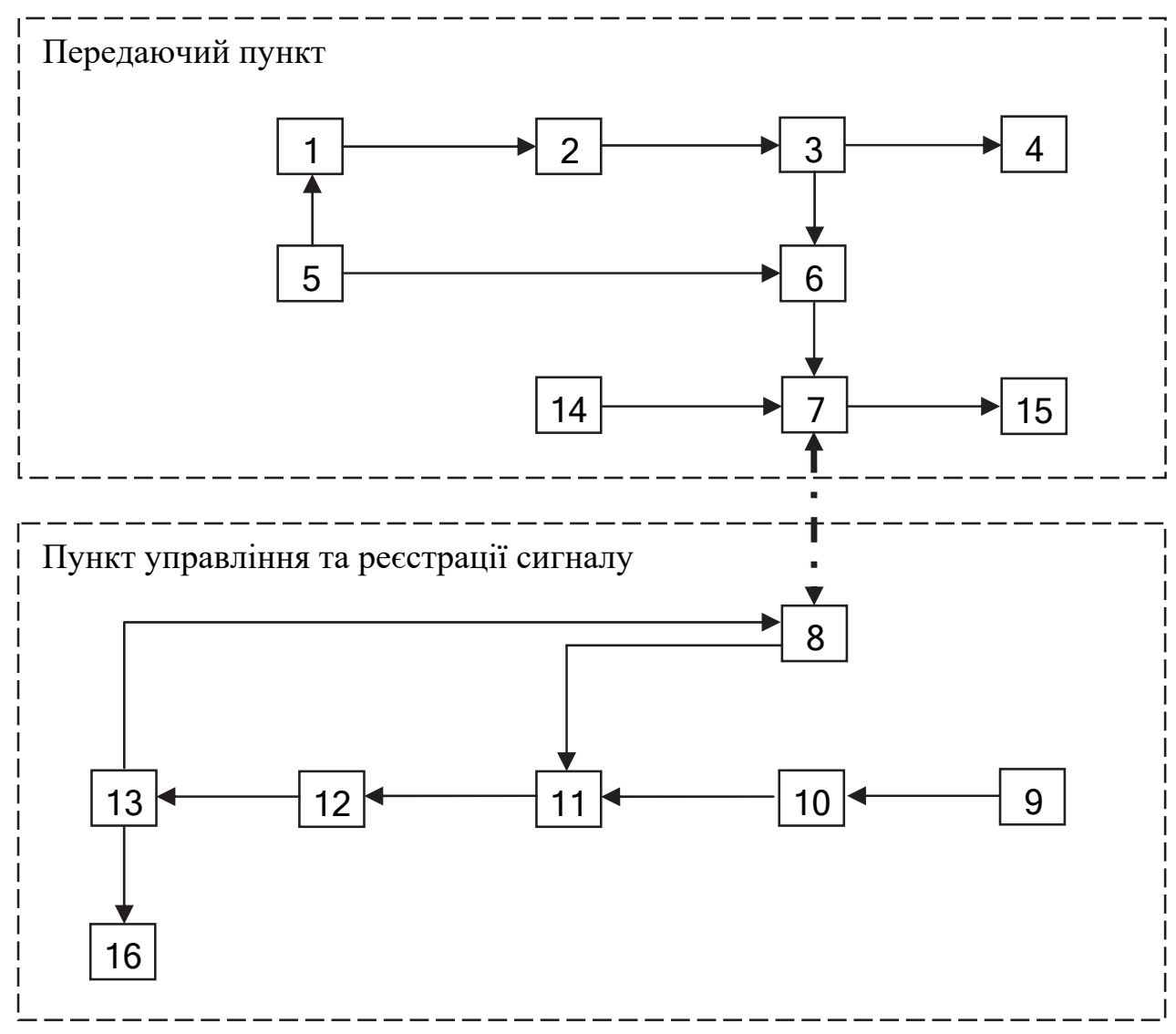

Рис. 2. Структурно-логічна модель пристрою НРЛ на ДКП Джерело: розроблено авторами. 
Пристрій НРЛ на ДКП [8] включає (див. рис. 2) передаючий пункт, пункт управління і реєстрації сигналу, причому передаючий пункт містить передавач 1, блок фільтрації 2, спрямовуючий відгалужувач 3 , випромінюючу антену 4 , хронізатор 5 , формувач опорної напруги 6 , блок передачі опорного сигналу 7, пункт управління і реєстрації сигналу містить блок прийому опорного сигналу 8, антену прийому гармонічних сигналів 9, фільтр гармонічних сигналів 10, приймач 11 , блок обробки сигналу 12 , блок відображення сигналу 13 , передаючий пункт додатково містить блок навігації 14, пристрій маркування 15, пункт управління і реєстрації сигналу додатково містить блок відображення мінної обстановки 16.

Запропонований пристрій пошуку та виявлення ВП з НДЦ володіє багатьма властивостями, які можуть проявлятися при їх створенні та експлуатації. Вони визначаються в основному призначенням, принципом дії та умовами застосування при виконанні завдань. До властивостей засобів (комплексів) пошуку та виявлення ВП з НДЦ згідно [11] можуть бути віднесені: продуктивність, маневреність, транспортабельність, живучість (стійкість), універсальність, адаптивність, автономність, надійність, ергономічність та економічність.

Продуктивність - це властивість, що характеризує спроможність засобів (комплексів) пошуку та виявлення ВП з НДЦ виконувати той або інший обсяг робіт в одиницю часу у визначених умовах експлуатації.

Розрізняють три види продуктивності: конструктивну, технічну та експлуатаційну [11].

Маневреність, як правило, розглядається як складна властивість зразка роботизованого комплексу розмінування, до складу комплекту якого входить ДКРЛК пошуку та виявлення ВП з НДЦ, що включає прохідність, рухливість, повороткість та керованість [11].

Транспортабельність - властивість, що характеризує пристосованість ДКРЛК пошуку та виявлення ВП з НДЦ до перевезення різними видами транспорту.

Маневреність та транспортабельність часто поєднують в єдину властивість - мобільність [11].

Живучість - властивість, яка характеризує ступінь стійкості ДКРЛК пошуку та виявлення ВП з НДЦ до впливу факторів ураження різних видів зброї [11].

Універсальність - пристосованість ДКРЛК пошуку та виявлення ВП з НДЦ до виконання декількох функцій. Визначений клас ДКРЛК пошуку та виявлення ВП з НДЦ за властивістю універсальність пропонується оцінювати параметром функціональної повноти, який характеризує ступінь повноти реалізації всіх функцій процесу пошуку та виявлення ВП з НДЦ [11].

Aдаптивність - властивість, яка характеризує максимальну пристосованість ДКРЛК пошуку та виявлення ВП з НДЦ до виконання завдань за призначенням як в умовах ведення бойових дій, так й в межах гуманітарного розмінування.

Автономність - пристосованість ДКРЛК пошуку та виявлення ВП з НДЦ функціонувати тривалий час у районах виконання завдань, у відриві від стаціонарного базування. Автономність забезпечується: можливістю ДКРЛК пошуку та виявлення ВП 3 НДЦ самостійно виконувати весь перелік робіт згідно ситуації їх застосування; енергозабезпеченням від автономних джерел живлення; запасом ходу та самостійним всебічним забезпеченням [11].

Надійність - властивість ДКРЛК пошуку та виявлення ВП з НДЦ зберігати у часі у встановлених межах значення всіх параметрів, що характеризують спроможність виконувати потрібні функції в заданих режимах та умовах застосування, технічного обслуговування, ремонтів, зберігання та транспортування [11].

Безвідмовність - властивість ДКРЛК пошуку та виявлення ВП з НДЦ зберігати працездатний стан в термін деякого (заданого) часу або деякого напрацювання (тривалості роботи).

Довговічність - властивість ДКРЛК пошуку та виявлення ВП з НДЦ зберігати працездатний стан до настання граничного стану (працездатності) при встановленій системі технічного обслуговування та ремонту.

Ремонтопридатність - властивість ДКРЛК пошуку та виявлення ВП з НДЦ, яка полягає в пристосованості до попередження і виявлення причин виникнення відмов (повної або часткової втрати працездатності), пошкоджень та підтримання і відновлення працездатного стану шляхом проведення технічних обслуговувань та ремонтів.

Зберігаємість - властивість ДКРЛК пошуку та виявлення ВП з НДЦ зберігати значення показників безвідмовності, довговічності та ремонтопридатності протягом та після зберігання або транспортування.

Ергономічність - властивість, яка характеризує пристосованість ДКРЛК пошуку та виявлення ВП з НДЦ до взаємодії з людиною [11].

Економічність - властивість, яка характеризує ДКРЛК пошуку та виявлення ВП з НДЦ щодо величини затрат матеріальних ресурсів на іiі виробництво, використання та зберігання [11]. Найбільш загальним параметром економічності ДКРЛК пошуку та виявлення ВП з НДЦ є питома собівартість одиниці роботи, що виконується зразком (комплексом, системою) за своїм основним призначенням як у ході 
операції (бойових дій), так й під час гуманітарного розмінування.

Всі зазначені властивості, які визначають концептуальний образ зразка перспективного ДКРЛК пошуку та виявлення ВП з НДЦ, повинні реалізовуватися шляхом встановлення вимог до показників, які б забезпечили визначені властивості. До основних 3 цих показників відносяться: функціональні показники; тактичні показники; технічні показники; конструктивні показники; часові показники; ергономічні показники; експлуатаційні показники.

\section{Висновки}

Таким чином, в результаті досліджень розроблено науково-методичний підхід щодо обгрунтуван- ня тактико-технічних вимог до ДКРЛК пошуку та виявлення ВП з НДЦ, що включає сукупність процедур та розроблених і удосконалених математичних моделей та дозволяє комплексно обгрунтувати вимоги до їх основних характеристик та показників.

Запропоновано структурно-логічну модель пристрою НРЛ на ДКП, яка, на відміну від існуючих, додатково містить блок навігації, пристрій маркування, пункт управління і реєстрації сигналу, блок відображення мінної обстановки.

Як напрямок подальших досліджень є розробка математичної моделі пошуку та виявлення ВП 3 НДЦ методом НРЛ із врахуванням розроблених технічних рішень та структурно-логічної моделі пристрою НРЛ на ДКП.

\section{Список літератури}

1. Жуков С. Опыт разминирования местности в условиях локальных военных конфликтов / С. Жуков // Зарубежное военное обозрение. - 1998. - № 6. - С. 14-19.

2. Нижаловський А.М. Минная война в Абхазии / А.М. Нижаловський // Армейский сборник. - 1999. - № 1. C. 26-29.

3. Экзаменует «горячая точка» // Армейский сборник. - 2000. - № 1. - С. 34-38.

4. Підсумковий звіт про виконання бойових завдань саперними підрозділами ЗС України в Ісламській Республіці Афганістан у складі Литовської групи з реконструкції провінції Гор (ГРП) за період з листопада 2010 р. по листопад 2011 p. - К.: ГШ ЗСУ, 2012. - 47 c.

5. Дії підрозділів на території, де можливе застосування саморобних вибухових пристроїв: методичний посібник. - К: ГУОЗ, 2012. -57 с.

6. Вопросы подповерхностной радиолокации / под ред. А.Ю. Гринева. - М.: Радиотехника, 2005. -416 c.

7. LANDMARK Making Land-Mine Detection and Removal Practical. - Access mode: https://www.llnl.gov/str/ Azevedo.html.

8. Варяница-Рощупкина Л.А. Оптимизация длительности зондирующего сверхширокополосного импульсного сигнала в задаче обнаружения подповерхностных объектов / Л.А. Варяница-Рощупкина, Г.П. Почанин // Радиофизика и электроника. - 2011. - Т. 2. - № 4. - С. 27-40. $144 \mathrm{c}$.

9. Щербаков Г.Н. Обнаружение скрытых объектов: монография / Г.Н. Щербаков. - М.: Арбат-Информ, 2004. -

10. Щербаков Г.Н. Новые методы обнаружения скрытых объектов: монография / Г.Н. Щербаков. - М.: ООО Эльф ИПР, 2011. - $503 \mathrm{c}$.

11. Денисенко О.М. Математична модель виявлення вибухонебезпечних предметів пошуковим пристроєм з радіолокаційним способом виявлення, встановленим на легких броньованих машинах / О.М. Денисенко // Труди університету: зб. наук. праць. - К.: НУОУ, 2011. - № 52. - С. 54-58.

12. Коцюруба В.І. Моделювання процесу пошуку і виявлення ВНП радіолокаційним методом / В.І. Коцюруба // Сучасні інформаційні технології у сфері безпеки і оборони. - К.: НУОУ, 2015. - № 2(23). - С. 65-69.

13. Обгрунтування раціональної комбінації методів виявлення ВНП для пошукових пристроїв РТК розмінування / B.I. Коцюруба, М.О. Шишанов, І.П. Даценко, О.М. Гусляков, С.М. Гімбер // Збірник наукових праць Центрального науково-дослідного інституту озброєння і військової техніки Збройних Сил України. - К.: ЦНДІ ОВТ ЗСУ, 2015. - № 4(59). - C. $179-186$.

14. Пристрій нелінійної радіолокації: заявка на патент винахід (корисну модель) №U202003397 Україна / Смольков О.Ю., Коцюруба В.І., Дачковський В.О. Заяв. 04.06.2020.

15. Устройство нелинейной радиолокации: патент Российской Федерации № 2474839, G01S 13/02, 2011.

16. Устройство нелинейной радиолокации: патент Российской Федерации № 139761, G01G 13/02, 2013.

17. Машины инженерного вооружения. Часть I. - М.: Воениздат, 1986. - 424 с.

18. Офіційний сайт Міністерства оборони України. IMAS 07.12 Контроль якості в протимінній діяльності. Перше видання 01 жовтня 2001 р. (Поправка 6, червень 2013 р.). - 27 с. - Режим доступу: http://www.mil.gov.ua/ministry/ normativno-pravova-baza/standarti.html.

\section{Відомості про авторів:}

\section{Смольков Олександр Юрійович}

старший викладач Національного університету

оборони України ім. І. Черняховського,

Київ, Україна

https://orcid.org/0000-0001-7351-393X

\section{Information about the authors:}

\author{
Oleksandr Smolkov \\ Senior Instructor of Ivan Chernyakhovsky \\ National Defense University of Ukraine, \\ Kyiv, Ukraine \\ https://orcid.org/0000-0001-7351-393X
}


Коцюруба Володимир Іванович

доктор технічних наук доцент

професор кафедри Національного університету

оборони України ім. І. Черняховського,

Київ, Україна

https://orcid.org/0000-0001-6565-9576

\section{Гунбін Костянтин Юрійович}

доцент кафедри Національної академії

Національної гвардії України,

Харків, Україна

https://orcid.org/0000-0002-8414-2916
Volodymyr Kotsiuruba

Doctor of Technical Sciences Associate Professor

Professor of Department of Ivan Chernyakhovsky

National Defense University of Ukraine,

Kyiv, Ukraine

https://orcid.org/0000-0001-6565-9576

\section{Konstantin Hunbin}

Senior Lecturer of National Academy

of the National Guard of Ukraine,

Kharkiv, Ukraine

https://orcid.org/0000-0002-8414-2916

\title{
НАУЧНО-МЕТОДИЧЕСКИЙ ПОДХОД К ОБОСНОВАНИЮ ТРЕБОВАНИЙ К ДИСТАНЦИОННО-УПРАВЛЯЕМЫМ РАДИОЛОКАЦИОННЫМ КОМПЛЕКСАМ ОБНАРУЖЕНИЯ ВЗРЫВНЫХ УСТРОЙСТВ С НЕКОНТАКТНЫМИ ДАТЧИКАМИ ЦЕЛИ
}

\author{
А.Ю. Смольков, В.И. Коцюруба, К.Ю. Гунбин
}

Увеличение применения взрывных устройств с неконтактными датчиками иели определяет необходимость углубленного исследования вопросов развития средств поиска и обнаружения взрывных устройств данного типа. Предложена усовершенствованная комплексная методика технического обоснования тактико-технических требований к дистанционно-управляемым радиолокационным комплексам поиска и обнаружения взрывных устройств с неконтактными датчиками иели.

Ключевые слова: взрывные устройства, неконтактный датчик иели, дистаниионно-управляемый радиолокаиионный комплекс.

\section{SCIENTIFIC AND METHODOLOGICAL APPROACH TO SUBSTANTIATION OF REQUIREMENTS FOR REMOTE-CONTROLLED RADAR COMPLEXES FOR DETECTION OF EXPLOSIVE EXAMPLES WITH NON-CONTACT TARGET SENSORS}

\author{
O. Smolkov, V. Kotsiurba, K. Hunbin
}

The increasing use of explosive devices with non-contact target sensors determines the need for in-depth study of the development of search and detection of explosive devices of this type. An improved complex method of technical substantiation of tactical and technical requirements for remote-controlled radar systems for search and detection of explosive devices with noncontact target sensors is proposed, which includes a set of procedures and developed and improved mathematical models.

The disadvantages of existing devices based on the method of nonlinear radar are that they do not allow fixing, transmitting coordinates and marking the location of explosive devices with non-contact sensors with nonlinear characteristics, and to form and display the geographic information layer of the mine in real time. Therefore, the authors proposed a device for searching and detecting explosive devices with non-contact target sensors. It is planned to install the proposed device on remotecontrolled platform, in particular, a helicopter-type unmanned aerial vehicle. This will achieve the same properties as performance, maneuverability, portability, survivability (stability), versatility, adaptability, autonomy, reliability, ergonomics and economy. Some indicators of these properties can be adjusted to appear at the stage of creation and operation. The essence of the technical solution is given and the improved structural and logical model of the perspective device on the basis of a method of nonlinear radar on remote-controlled platform is given.

The direction of further research is the development of mathematical model of search and detection of explosive devices with non-contact target sensors based on the method of nonlinear radar, taking into account the developed technical solutions and structural-logical model of the device.

Keywords: explosive devices, non-contact target sensor, remote-controlled radar complex. 